\title{
Dairy Woes in Wisconsin: What about the Amish?
}

\author{
John A. Cross \\ Professor Emeritus of Geography \\ University of Wisconsin - Oshkosh \\ cross@uwosh.edu
}

\begin{abstract}
Wisconsin has steadily lost dairy farms for decades, yet the number of Amish dairy herds grew both numerically and proportionately into early 2018. Facing low milk prices, the overall rate of loss of dairy farms in Wisconsin accelerated since then. During 2019, the state lost over $1 \%$ of its dairy herds monthly, losing two to three herds daily. The expansion of Amish dairying also ended. Between April 1, 2018, when Wisconsin had 1,160 Amish dairy herds or $12.9 \%$ of the state's total, and November 1, 2019, the state lost 165 Amish herds. Losses are continuing.

This paper focuses on the impact of the departure of many Amish farms from dairying, relying on examination of dairy producer licenses and a survey of bishops and ministers in Wisconsin's Amish church districts. The loss of Amish herds of dairy cows is greater than the overall departure of the Amish from dairying, inasmuch as the Amish have nearly doubled their milk goat herds over the past five years. Those settlements producing milk transported in cans have been more likely to leave dairying unless their community operates its own cheese factory. Yet dairying is declining in most Amish communities, other than in several recently established settlements. Expanding involvement in growing produce and in woodworking were seen.
\end{abstract}

Submitted September 26, 2020; accepted December 17, 2020; published March 24, 2021

https://doi.org/10.18061/jpac.v1i2.7935

Keywords: Wisconsin, Amish, dairy farming, milk prices, occupational change

$\mathrm{T}$ he past decade has proven challenging to most dairy farmers, who faced a combination of low milk prices, overproduction, uncertain export markets, and a continuation of the restructuring of the industry, as mega-dairies, which benefit from many economies of scale, expand their domination. This paper explores how the Amish have fared in "America's Dairyland," given that while the overall number of Wisconsin's dairy farmers declined over the past several decades, the number of Amish dairy farmers grew until early 2018. For several decades, scholars have reported that many Amish settlements nationwide have been moving away from dairying, or even farming in general, as their primary source of income (Kraybill et al., 2013). In contrast, 58.1\% of Wisconsin's Amish households remained employed in farming in 2014, and dairying engaged $37.4 \%$ of them (Cross, 2018).

Wisconsin became attractive to Amish dairy farmers several decades ago. The state has long had an oversupply of dairy farms. Indeed, the Dairy Termination Program of 1986-87 accepted nearly 1,700 Wisconsin herds for elimination, yet "Wisconsin's acceptance rate (17.4\%) was by far the nation's lowest" (Cross, 1989, p. 14). While these dairy farms were ineligible to return to 
dairying for a half decade, almost 8,000 other Wisconsin dairy farmers had submitted buyout requests that were rejected, clearly illustrating the desire of many dairy farmers to get out of dairying. The reaching of retirement age by many Wisconsin dairy farmers, and their children's lack of interest in continuing to operate the family farm, placed many smaller operations on the market (Bentley \& Saupe, 1990; Cross, 2006). As well, the rapid growth of mega-dairy farms with their economies of scale and greater efficiency of production placed smaller operators at a competitive disadvantage (National Agricultural Statistics Service, Wisconsin Field Office [NASS-W], 2010). At the same time, population growth led to farmland shortages and escalating prices within many well-established Amish settlements in Pennsylvania, Ohio, and Indiana, pushing those families that wished to remain in dairying to seek the relatively inexpensive farmland that was available elsewhere (Anderson \& Kendra, 2015), including in Wisconsin.

Beginning in 2017, Wisconsin began seeing a growing loss of dairy farms in response to oversupply, changing demand, loss of export markets, and declining prices (see Cross, 2021). By March 2018, when those losses were accelerating, Amish farmers had joined the exodus. This paper delves into those circumstances that influenced both the expansion and the contraction of Amish dairying, reporting on an analysis of both spatial and temporal patterns of change in Amish dairying, as revealed by dairy producer license data and a survey of Wisconsin's Amish bishops and ministers conducted during summer 2019.

This paper is divided into three parts, following two methodological explanations. The first part reviews changes in the total number of dairy farmers in Wisconsin and the number of Amish dairy farms during the two decades leading up to 2018. The second part describes the dramatic decline of dairy farmers - both Amish and non-Amish - since that time. The third section reports the findings from the survey.

\section{Study of Dairy Farming at the Town Level}

The change in number of Amish dairy herds is studied at the civil town (Wisconsin's equivalent of the township) level, facilitated by examination of dairy producer licenses from the Wisconsin Department of Agriculture, Trade, and Consumer Protection (WDATCP, 2012, 2018, 2019a, 2019b, 2019c, 2020a, \& 2020b). These license listings have been obtained by the author annually, typically in March or April to approximately match the date of statistics reported by the Wisconsin Agricultural Statistics Service (WASS, 2012, 2018, 2019, 2020) in its annual statistical reports. Because summary statistics are posted monthly, typically on the first of the month, on the NASS-W website, the author purchased additional license listings following noticeable movements in the dairy herd numbers. These listings were acquired relatively early in the month, but include a slightly smaller number of dairy license holders than are indicated for the first of the month. The digital license listings provide each dairy producer's name, mailing address, telephone number (if any), and the county, town, and section in which the barn is located. They facilitate the detection of trends that would not be observable by just looking at county data, such as in census reports or the statistics released by the Wisconsin Agricultural Statistics Service. 
The author plotted net dairy herd losses by town between 1989 and 1999 and, after excluding those towns with fewer than 30 dairy herds, discovered 22 towns that had lost fewer than $20 \%$ of their herds, even though the state's overall loss was nearly $40 \%$. All of these towns, located in Clark, Taylor, Monroe, Vernon, and Sauk Counties, were areas known to have growing Amish populations (Cross, 2001) or were in Grant County, whose developing Amish settlements become known shortly thereafter (Cross, 2004). Subsequent work focused on tying specific dairy herds to Amish operators.

\section{Identification of the Amish}

The presence of Amish dairy farmers can be determined from the names on the dairy producer licenses. Many surnames in Wisconsin are unvaryingly associated with the Amish, such as Beiler, Borntrager (also Borntreger and Bontrager), Gingerich, Hershberger, Schrock, Stoltzfus, and Troyer, among others. Others, such as Yoder, are almost always Amish. Thus, many Amish dairy farmers can easily be identified by their surnames (Smith, 1968; Kent \& Neugebauer, 1990; Cross, 2003). However, the most common Amish surname among Wisconsin farmers is Miller, of which about three-quarters are Amish. Yet even most Amish Millers are also identifiable, given the presence of Amish directories that provide a wealth of information regarding households in most Amish settlements (Miller, 2014; Yoder, 2018). The most conservative Amish communities, typically under one tenth of the total, do not share their information in such directories. However, the names and addresses of their ministers and bishops are annually listed by Raber (2019), which helps locate about one fifth of their households. Proximity of unknown Millers to these Amish households, plus the frequent usage of Old Testament given names uncommon within the general population, ensures that most Amish Millers are identified.

\section{Declining Total Dairy Farms, Increasing Amish Dairy Farms}

Wisconsin had 14,265 herds of milk cows as of April 1, 2007, a number that declined by $18.4 \%$ over the following five years. About 980 of Wisconsin's dairy farmers were Amish in 2007. The total number of Wisconsin farms with milk cows, as shown by dairy producer licenses, declined from 11,637 to 9,236 between April 1, 2012, and April 1, 2017 (NASS-W, 2020a), yet the number of Amish dairy herds increased.

In April 2012, Wisconsin had 926 Amish dairy farms with milk cows, plus 86 Amish goat's milk farms and 14 Amish sheep's milk herds. Thus, the Amish accounted for $8.0 \%$ of the state's cow's milk dairy farms, 38.7\% of Wisconsin's goat's milk farms, and $31.8 \%$ of its sheep's milk farms. Considering all three types of milk, the Amish comprised nearly 9\% of the state's dairy farmers. Looking at the Amish engagement in dairying at the town level showed that they had come to dominate dairying locally. In 2012 Amish dairy farms comprised at least $50 \%$ of the total in 25 Wisconsin towns (Figure 1). Amish dairy farmers ran between a quarter and a half of all dairy herds in an additional 52 towns. 
Figure 1

Percentage of Dairy Farmers in Each Wisconsin Town Who Were Amish in 2012

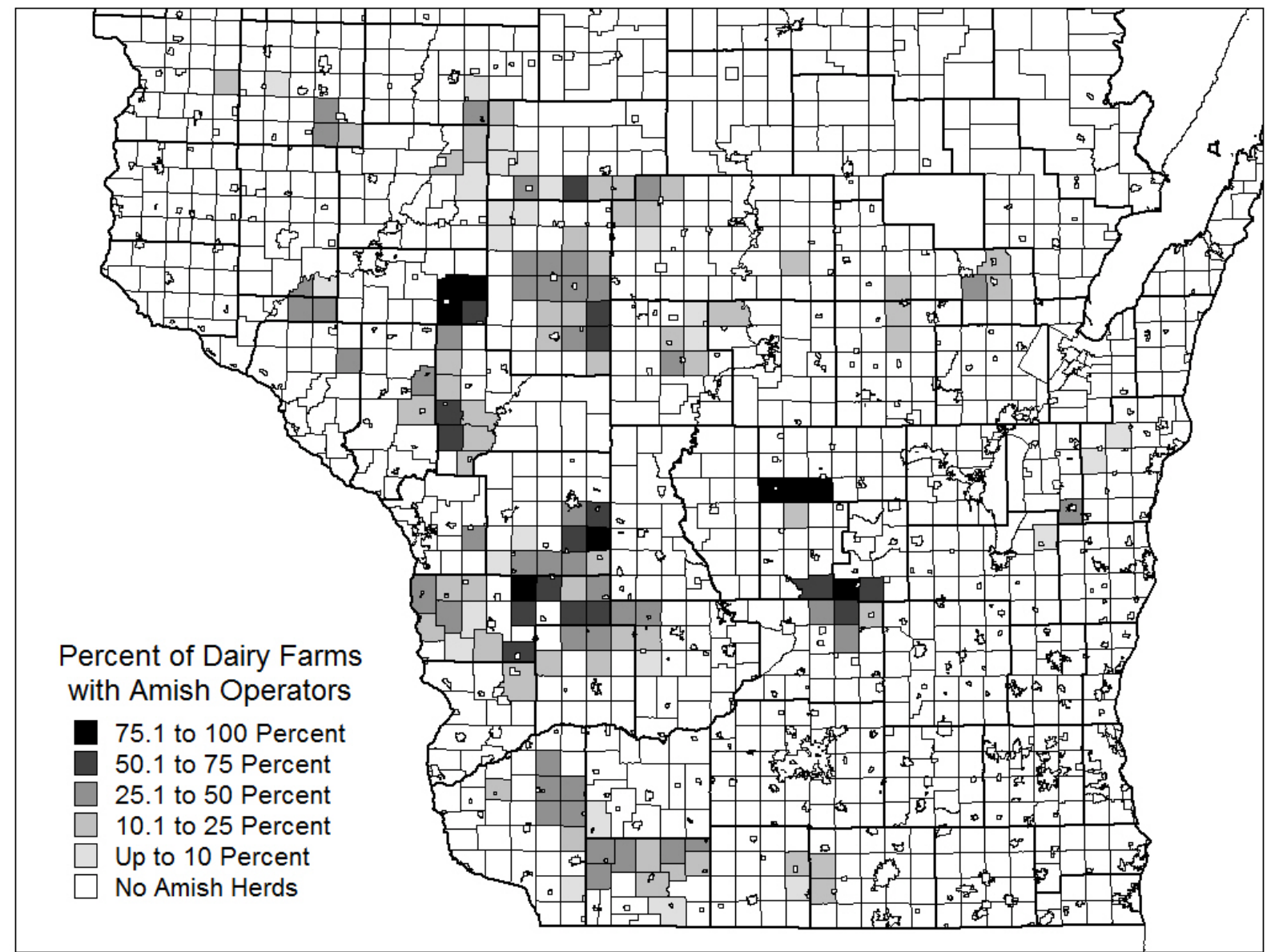

Note. Calculated and mapped by the author using data from WDATCP 2012.

While the total number of Wisconsin dairy farmers fell steadily into 2017, Amish dairy farmers increased by over 100. The rate of decline in dairying overall accelerated between 2017 and 2018, with Wisconsin having 8,649 dairy cow herds on April 1, 2018. Yet the number of Amish dairy herds had increased, although more in some settlements than in others. The number of Amish settlements (Figure 2) in the state had grown to 55 (Young Center, 2018), and the proportion of the state's dairy farms that were Amish was increasing at a more dramatic rate, even though the proportion of Wisconsin's Amish households who had dairy herds was declining (Cross, 2018). 
Figure 2

Amish Settlements in Wisconsin in 2019

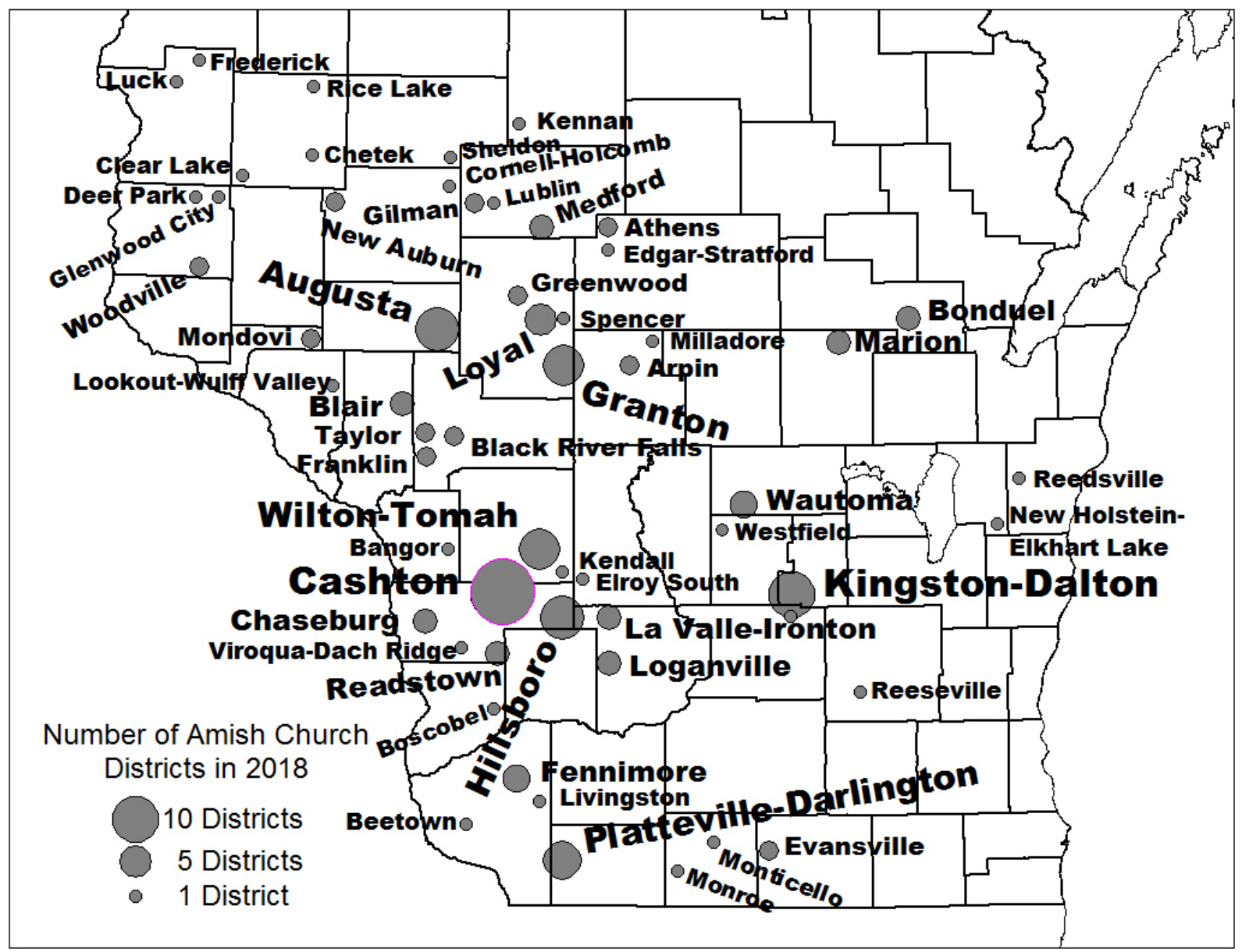

Note. Mapped by the author using data in Raber (2019) and Donnermeyer (2019).

By April 2018, Wisconsin had 1,160 Amish dairy herds, including those of cows, goats, and sheep. Figure 3 illustrates the spatial pattern of change from 2002 to 2018. Wisconsin's total number of dairy herds, of all three types of animals, was 9,004 . Thus, $12.9 \%$ of the state's total dairy herds resided on Amish farms. Of those dairy farms producing cow's milk, 11.1\% were Amish operated, while the Amish had 201 dairy goat herds, 56.5\% of the state's total. 
Figure 3

Change in Number of Amish Dairy Herds per Town in Wisconsin between 2002 and 2018

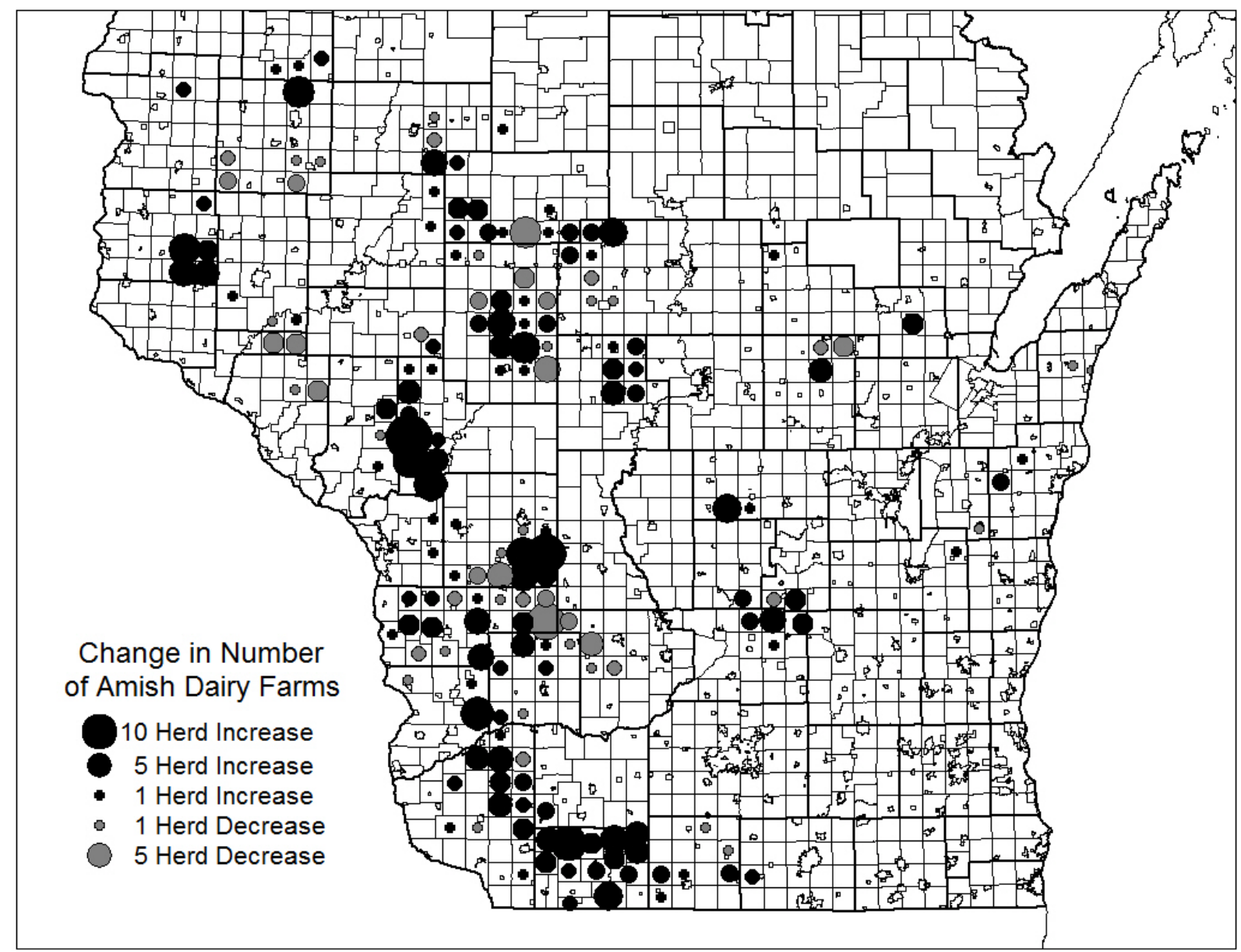

Note. Data compiled and mapped by the author from WDATCP 2002 and 2018.

Amish dairy herds were found in one-sixth of those Wisconsin towns that had at least one dairy farm in April 2018. Within many towns, they comprised a large share of the dairy farms. (See Figure 4.) In 12 towns, the Amish operated over $75 \%$ of all of the dairy herds, while their herds accounted for over $50 \%$ of the herds in another 30 towns, a $68 \%$ increase since 2012 . In 51 towns in Wisconsin, the Amish operated at least half of the dairy farms. They operated $25.0 \%$ to $49.9 \%$ of the dairy herds in an additional 59 towns. 


\section{Figure 4}

Percentage of Dairy Farmers in Each Wisconsin Town Who Were Amish in April 2018

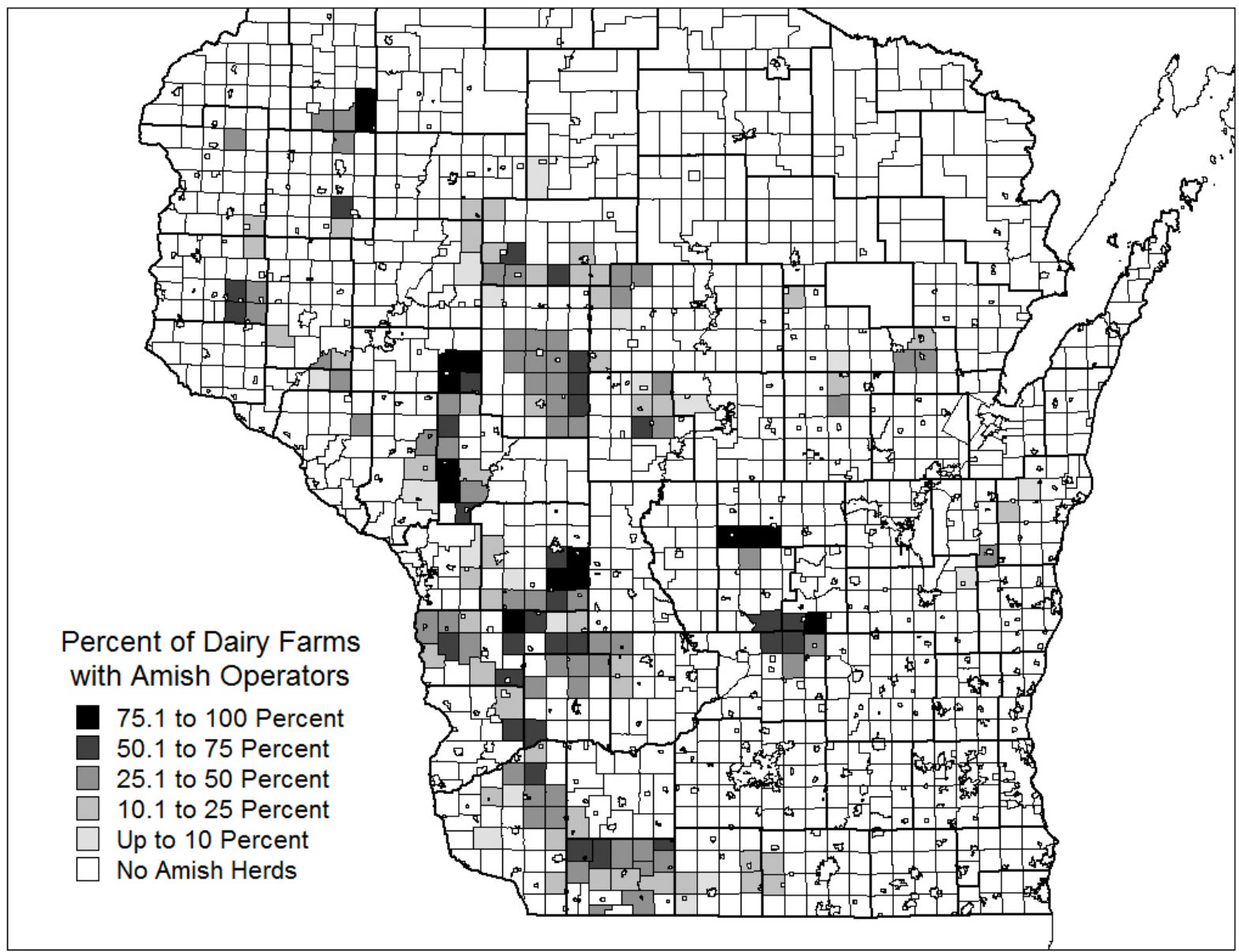

Note. Calculated and mapped by the author using data from WDATCP 2018.

The largest clusters of towns where Amish dominated dairying extended from southwest Wisconsin through west central Wisconsin into the southern part of northcentral Wisconsin. This includes those Amish dairymen in Grant and Lafayette Counties in southwestern Wisconsin and those in Shawano County of northeastern Wisconsin, who are largely producers of Grade A milk, plus those around the Vernon and Monroe County settlements of Cashton, Hillsboro, and Wilton, who produce Grade B can milk and whose numbers had been relatively stable until early 2018.

\section{Decline in Number of Amish Dairy Farms beginning in 2018}

The steady expansion in the number of Wisconsin's Amish dairy herds came to an abrupt end during early 2018. Those who shipped their milk in cans, living in the most conservative Amish settlements, encountered a variety of obstacles, including milk buyers who decided to cease buying can milk (Barrett, 2018, 2019), which can legally only be used for manufacturing purposes. Producers of can milk have smaller herds than Amish producers of Grade A milk, which is more 
attractive to buyers and brings greater revenue (Cross, 2014). Dairy producer license data do not identify specific dairy operators who produce can milk, but the geographic spread of cow's milk herds that ship milk in cans (NASS-W, 2018) supports the conclusion that Amish farmers account for over $99 \%$ of can milk producers. Undoubtedly, many Amish operators of goat's milk herds also use cans, but neither license data nor published statistics are available indicating their numbers. Nevertheless, information regarding the number of cow's milk producers using cans is available monthly, and it provides an excellent way of chronologically monitoring many of Wisconsin's Amish dairy farms.

Beginning in April 2018 (Table 1), we see a steady monthly drop in the number of Grade B can cow's milk producers, who are virtually all Amish. The number of dairy farms shipping their milk in cans dropped from 587 to 529 by March 1, 2019. A year later, 462 dairy farms used cans, and the number had fallen to 456 by July 2020. Based on an examination of dairy producer licenses, Wisconsin lost 92 Amish dairy herds between April 2018 and March 2019. Between March and November 2019, Wisconsin lost another 73 Amish dairy herds, leaving the state with 995 Amish herds, the smallest number since 2011. The rate of losses slowed beginning in the fall, and Wisconsin had 978 Amish dairy herds as of March 2020, a number that had fallen to 962 by July 2020.

\section{Table 1}

Wisconsin Cow Dairy Herds Producing Grade B Can Milk, January 1, 2018 - July 1, 2020

\begin{tabular}{|c|c|c|c|c|c|}
\hline Year and Month & $\begin{array}{l}\text { Number } \\
\text { of Herds }\end{array}$ & Year and Month & $\begin{array}{l}\text { Number } \\
\text { of Herds }\end{array}$ & Year and Month & $\begin{array}{l}\text { Number } \\
\text { of Herds }\end{array}$ \\
\hline 2018 - January & 594 & 2019 - January & 541 & 2020 - January & 470 \\
\hline 2018 - February & 594 & 2019 - February & 534 & 2020 - February & 465 \\
\hline 2018 - March & 593 & 2019 - March & 529 & 2020 - March & 462 \\
\hline 2018 - April & 587 & 2019 - April & 516 & 2020 - April & 460 \\
\hline 2018 - May & 577 & 2019 - May & 507 & 2020 - May & 458 \\
\hline 2018 - June & 573 & 2019 - June & 496 & 2020 - June & 456 \\
\hline 2018 - July & 567 & 2019 - July & 492 & 2020 - July & 456 \\
\hline 2018 - August & 566 & 2019 - August & 488 & & \\
\hline 2018 - September & 558 & 2019 - September & 481 & & \\
\hline 2018 - October & 551 & 2019 - October & 469 & & \\
\hline 2018 - November & 546 & 2019 - November & 470 & & \\
\hline 2018 - December & 542 & 2019 - December & 460 & & \\
\hline
\end{tabular}

Note. Data from monthly reports from NASS-W (2018-2020).

\section{Greatest Numerical Losses}

The greatest numerical declines in Amish dairy farms are seen in communities that utilize milk cans, especially where the Amish do not have access to a nearby cheese factory that processes their milk. Thus, the Augusta settlement (Figure 5) saw greater losses than did the larger Cashton and Kingston- 
Dalton settlements, where the Amish either founded or operate cheese factories (Grahn \& Wingate, 1988; Johnson, 2014; Shepel, 2019). Yet even there, plus in several Amish settlements that produce Grade A milk, declines are noted. The exceptions are largely around several recently established and growing Amish settlements in Chippewa and St. Croix Counties, plus growth in the Wautoma and Platteville-Darlington settlements, which store and ship their milk in bulk tanks (much of which is Grade A) rather than in milk cans. Arrivals coming from Pennsylvania contribute to the expansion of Amish settlements in Lafayette, Grant, and Crawford Counties. Growth in Amish dairying also occurred near the newest settlement of Westfield, as well as around Taylor and Franklin in Jackson County. Nevertheless, even after their decline in number, the Amish operated over half of all dairy farms in 38 towns in March 2019, a loss of only four since April 2018. Indeed, while the Amish lost 92 dairy herds during the 11-month period, the state overall lost 678 dairy herds.

\section{Figure 5}

Change in Number of Amish Dairy Herds per Wisconsin Town between April 2018 and March 2020

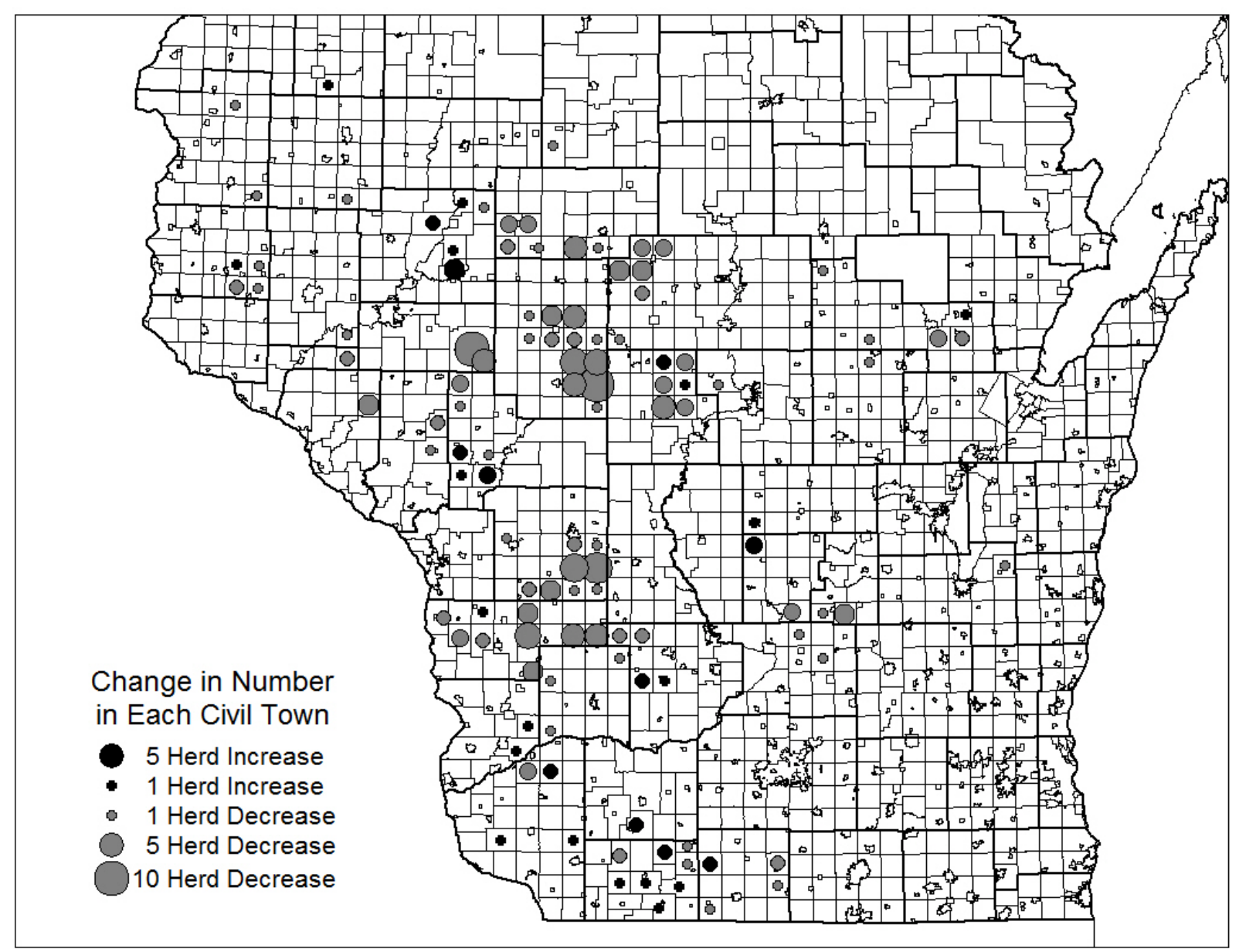

Note. Calculated and mapped by the author using data from WDATCP 2018 and 2020. 


\section{Largest Proportional Declines}

With the loss of 165 Amish dairy farms between April 2018 and November 2019, large proportional declines are particularly conspicuous in several locations (Figure 6). While some of the high percentages are simply an artifact of small numbers, such as when the only Amish dairy farm in a town ceased operation, as was the case of Price County's Town of Kennan, others appear to highlight occupational changes that were already underway in many Amish settlements.

\section{Figure 6}

Percent Change in Number of Amish Dairy Herds per Wisconsin Town between April 1, 2018 and November 1, 2019

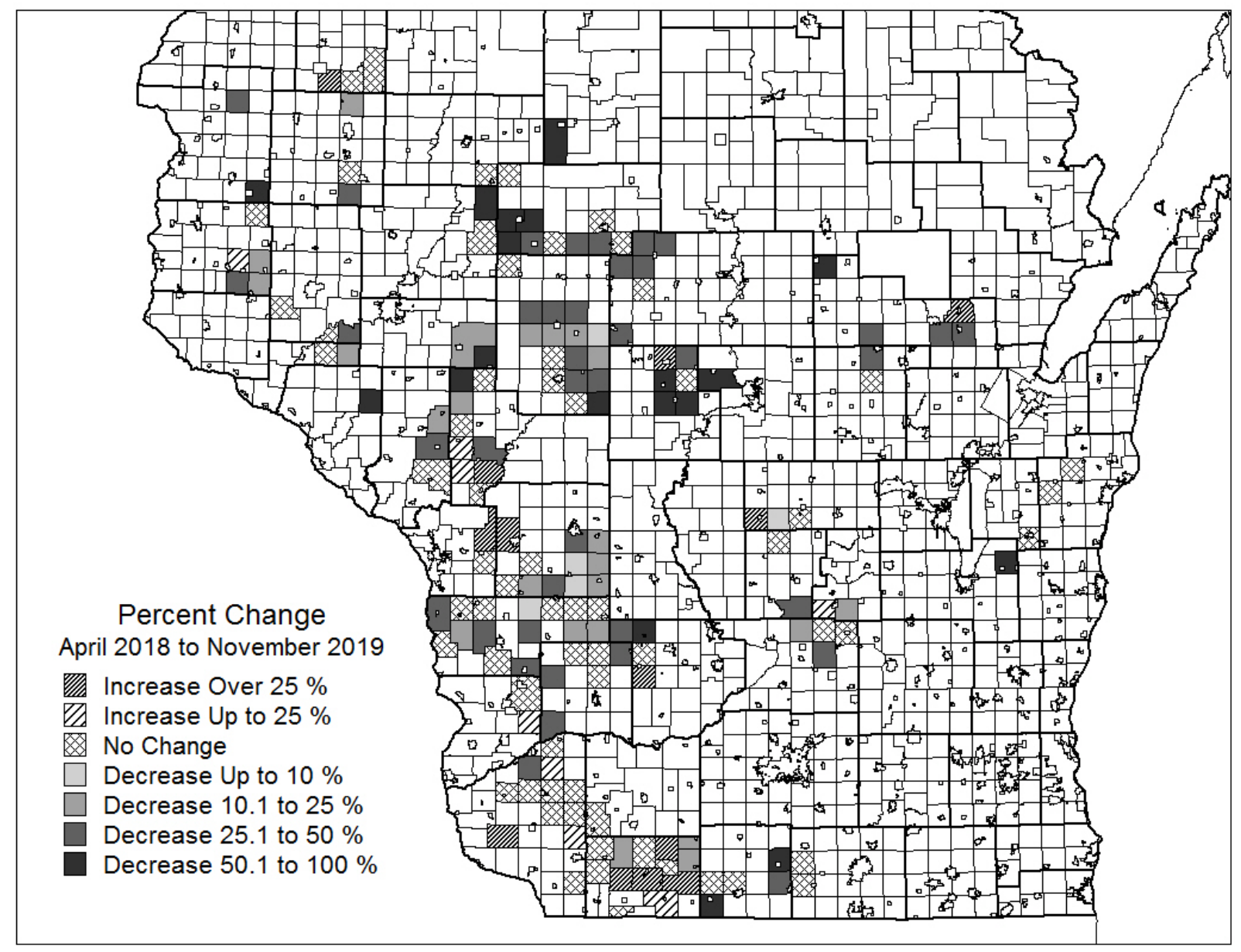

Note. Calculated and mapped by the author using data from WDATCP 2018 and 2019c.

A good example is Augusta, where sawmill-related occupations employed 30\% of Amish households in 2014 (Miller, 2014) and were rapidly growing (Cross, 2018), undoubtedly spurred by the closure of the local cheese factory that processed their can milk a decade earlier (Miller, 2009). In 2018, 79 Augusta households showed occupations involving sawmills or some type of woodworking (Yoder, 2018), compared with 64 that had licensed dairy herds that April. There the 
actual number of Amish dairy herds lost per town was large, as the Town of Bridge Creek in Eau Claire County lost ten herds between April 2018 and November 2019, while the adjacent Town of Fairchild lost five herds, representing losses of $18.2 \%$ and $55.6 \%$, respectively. Neither town lost any herds over the next four months.

Other towns losing both large numbers and percentages of their Amish dairy herds encompass the Granton Amish settlement. There the towns of Lynn and York in Clark County lost nine and seven herds (33.3\% and 43.8\%), respectively, over the same time period. By March 2020, the Town of Lynn had lost an additional Amish herd, while the Town of York's number was unchanged. While a greater proportion of the Amish households in Granton were engaged in farming in 2014 than were those in Augusta, Granton's farmers were more involved with produce farming (Miller, 2014; Cross, 2018), providing an occupational alternative to dairying. Amishoperated produce auction houses in both the Cashton and Kingston-Dalton settlements have encouraged produce farming. Woodworking activities have also grown in prominence (Cross, 2018).

\section{Increasing Milk Goat Herds}

Even with the declines in dairying, several things are clear. The Amish still have nearly a thousand dairy herds in Wisconsin, and within areas of the state, particularly where Amish producers utilize bulk tanks, their numbers are continuing to expand. While the majority of the Amish who have dairy herds have milk cows, the proportion with herds of dairy goats has been increasing. In April 2015, Wisconsin Amish farms had 120 dairy goat herds, plus two sheep's milk herds, with goats and sheep accounting for 11.2\% of all Amish dairy herds. In April 2018, the Amish had 201 goat herds, $17.3 \%$ of their total. By June 2019, there were 210 Amish dairy goat herds and five sheep's milk herds, or $20.6 \%$ of their total. While the number of Amish dairy goat herds had fallen to 187 by March 2020, plus three sheep's milk herds, they comprised 19.4\% of total Amish herds. Thus, the Amish in Wisconsin have dramatically increased their involvement with dairy goats, operating $60.3 \%$ of the state's milk goat herds, while their milking of cows has declined.

Dairy goat herds (Figure 7) are found disproportionately within certain Amish settlements, largely away from those communities that are most reliant on producing can cow's milk. Of Wisconsin's two largest Amish settlements, Kingston has no milk goat herds and Cashton has relatively few. While the Cashton settlement is spread across several towns in both Monroe and Vernon Counties, within the Town of Clinton, Vernon County, where Amish farmers have 68 dairy herds (the most of any town in the state), all but one contain milk cows, while the other has sheep. In contrast, the majority of Amish dairy farms in Beetown, Boscobel, Franklin, Reedsville, Rice Lake, Wautoma, and Woodville have milk goats. 
Figure 7

Percentage of Amish Dairy Farms in Each Wisconsin Town that Had Dairy Goat Herds in June 2019

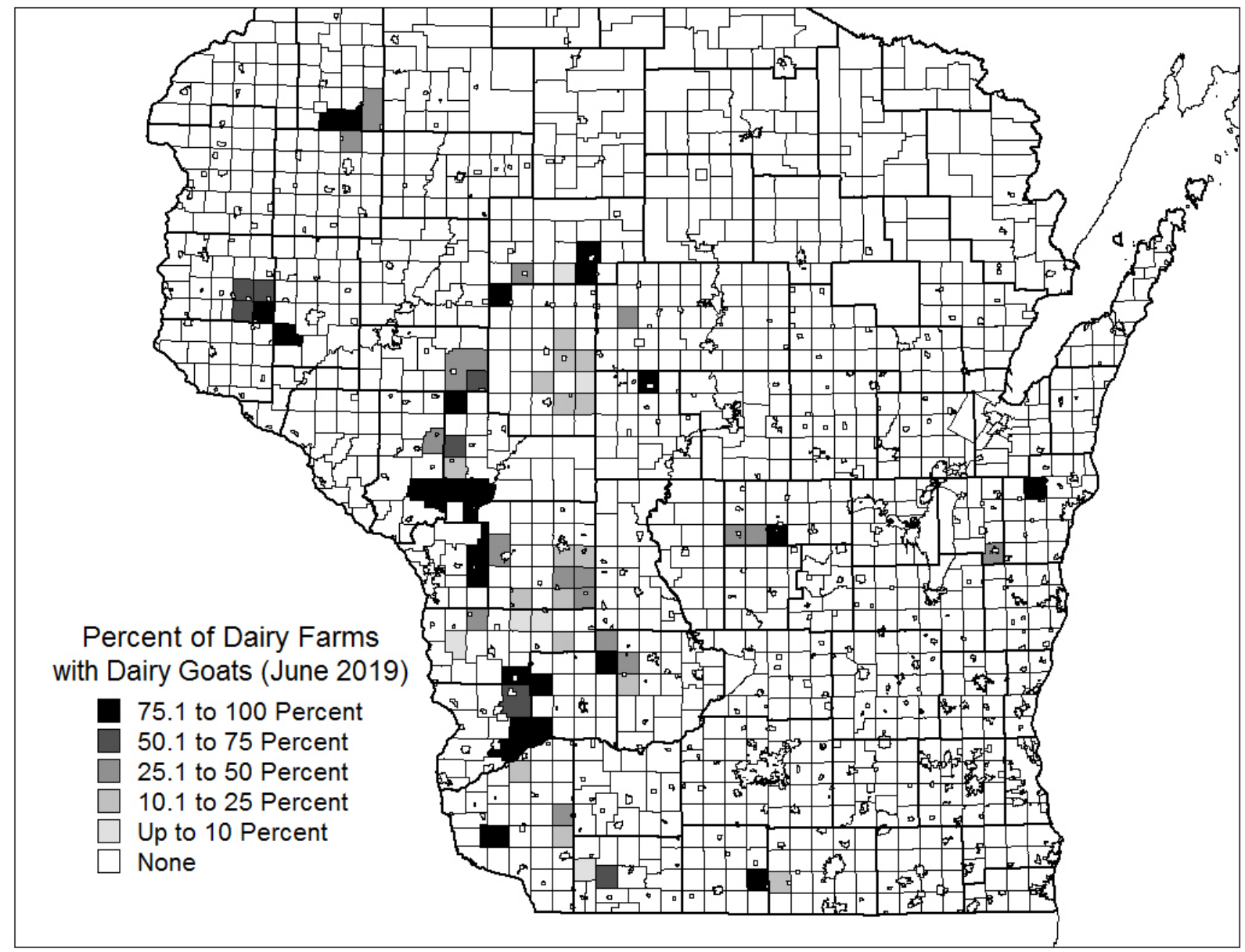

Note. Calculated and mapped by the author using data from WDATCP $2019 \mathrm{~b}$.

\section{Findings from Survey of Amish Bishops and Ministers}

The increase in dairy goat operations can be monitored via dairy producer licenses, yet many of the ongoing changes and the rationale for them, not only within dairying but in occupations in general, can be better understood by questioning the Amish. To gather such information, a twopage questionnaire was mailed on June 21, 2019, to a minister or bishop in 158 church districts in Wisconsin. Responses were received from 49 individuals within four weeks of the mailing, representing a $31.0 \%$ response rate. A second mailing of the survey was made to nonrespondents, bringing the total response rate up to $43.7 \%$, although many of the 69 respondents left some of the questions unanswered, particularly those concerning the future. Furthermore, several returned surveys reported combined statistics for the districts within a settlement, having been prepared by ministers or bishops working together. Thus, the respondents represented more than $45 \%$ of the state's Amish church districts. 


\section{Small Shift from Dairying}

Analysis of the survey responses indicate a small shift away from dairy farming, which has been the most widespread occupation of Wisconsin's Amish households (Cross, 2018), toward other occupations (Table 2). While two-thirds of the responding ministers and bishops anticipated no change in their district's engagement with dairying over the next six years, $21 \%$ saw it declining while $11.5 \%$ envisioned it increasing.

\section{Table 2}

Expected Change in Dairy Farming in Church District by 2025

\begin{tabular}{lcc}
\hline Question & Change & $\mathrm{N}=61$ \\
\hline "By 2025, do you expect that a larger or smaller & Larger Percent & $11.5 \%$ \\
percentage of the farmers in your church district will & Same Percent & $67.2 \%$ \\
have dairy herds?" & Smaller Percent & $21.3 \%$ \\
\hline
\end{tabular}

When asked to explain why they expected the percentage of Amish farmers with dairy herds to change over the next six years, those who indicated a larger percentage noted that the current low prices could only go higher, that organic milk demand would attract more producers, and that their community was transitioning from milk cows to goat milk herds. Consistent with dairy license data showing increasing interest in milk goats, a respondent from Woodville wrote, "At present we have 3 cow herds, 18 goat herds. We are focusing on all going to goat herds that have dairy, later this year."

Those bishops and ministers explaining why the percentage of Amish farmers with dairy herds would decline cited low milk prices, higher expenses, too many regulations, difficulties in obtaining a market for can milk, and "cheese factory trying to get rid of us." A respondent from the Cashton settlement explained, "Milk prices too low to compete with the mega-dairies." A commenter from Gilman noted that his district had dairy herds until late October 2018, explaining, "Price went bad, farmers forced to find another source of income," which involved a shop and sawmill. Explaining why he was uncertain about how to answer the question, a Fennimore minister wrote: "Depends if milk company will work around Sunday. We do not believe in picking up milk on Sunday. We can read so many places in Bible that the Lord wants us to hold the Sunday and rest on Sunday."

Although fewer respondents provided explanations about why the percentage would be the same as it was currently, their responses focused on concerns regarding milk prices and regulations, with one respondent noting that "creameries do not want small farmers" and another writing that it is "hard to ship small amounts of milk." Ministers and bishops from districts producing can milk were more likely to expect either increased or decreased percentages with dairy herds, yet the differences were not statistically significant. 
Survival Prospects of Amish versus Other Small Dairy Farmers. Given that Wisconsin has seen large drops in the numbers of both Amish dairymen and non-Amish farmers over the past year, the ministers were asked, "Compared with other Wisconsin farmers who milk fewer than a hundred cows, do you think Amish dairy farmers are more or less likely to remain in the dairy business?" (Table 3). Sixty-five percent of the respondents felt that Amish dairy farmers were more likely to remain in dairying. Reasons for this response focused on the Amish lifestyle, family and community help, and lower costs. A respondent from Taylor succinctly noted, "It's our livelihood, our way of raising our families, and we can operate cheaper than the English people." One from Cashton explained, "Our way of living is more likely to survive the dairy slump." A reply from Hillsboro noted that the Amish focused on a "niche market: Organic, Non-GMO, Grassfed" milk cows.

\section{Table 3}

Likelihood of Amish versus Non-Amish Farmers to Remain in Dairying

\begin{tabular}{|c|c|c|}
\hline Question & Expectation & $N=54$ \\
\hline \multirow{2}{*}{$\begin{array}{l}\text { "Compared with other Wisconsin farmers who milk fewer } \\
\text { than a hundred cows, do you think Amish dairy farmers } \\
\text { are more or less likely to remain in the dairy business?" }\end{array}$} & $\begin{array}{l}\text { Amish more likely to } \\
\text { remain in dairying }\end{array}$ & $64.8 \%$ \\
\hline & $\begin{array}{l}\text { Amish less likely to } \\
\text { remain in dairying }\end{array}$ & $35.2 \%$ \\
\hline
\end{tabular}

The Amish played a major role in the establishment of the Organic Valley Cooperative (DayFarnsworth et al., 2009). While current statistics are not available regarding the number of Amish organic milk producers providing milk to that cooperative, statewide 183 Amish dairy farms are named on a 2020 list of certified organic producers (U.S. Department of Agriculture, 2020). Thus, $19.0 \%$ of Wisconsin's Amish dairy herds were certified organic operations in 2020, and the Amish accounted for one-third of the state's organic dairy operations. Organic dairying clearly played a prominent role in the success of many Amish dairy farms, and organic producers were favorably positioned to experience an explosion in demand for their product with the onset of the pandemic (Eisen, 2020). In contrast, reasons given for the Amish being less likely to remain in dairying largely cited concerns of both Amish and non-Amish dairy farmers.

Respondents from Amish settlements where the sale of milk provided over half of the farm income (Table 4) were significantly more likely to indicate that the Amish were more likely to remain in dairying in comparison with small non-Amish dairy farms. Those respondents (Table 5) from districts that utilized milk cans rather than bulk tanks were also more likely to think that Amish dairy farmers were more likely to remain than small non-Amish dairy operators. Four of Wisconsin's Amish settlements were known to lack any dairy herds in 2014 (Cross, 2018). Although statistical tests involving cells with an expected count below five are prone to error, a chi-square test was run to determine how the attitudes about dairying of those ministers and 
bishops from districts without dairying compared with the attitudes of those in districts that had dairy herds (Table 6).

\section{Table 4}

Amish Likelihood to Remain in Dairying and Milk Sales Over Half of Farm Income

\begin{tabular}{lccc}
\hline "Compared with other Wisconsin farmers & & \multicolumn{2}{c}{$\begin{array}{c}\text { "Does the sale of milk provide over half of the farm } \\
\text { income to members of your church district?" }\end{array}$} \\
\cline { 2 - 4 } $\begin{array}{l}\text { who milk fewer than a hundred cows, do } \\
\text { you think Amish dairy farmers are more or } \\
\text { less likely to remain in the dairy business?" }\end{array}$ & Yes & No & $\begin{array}{c}\text { Total } \\
(\mathrm{N}=53)\end{array}$ \\
\hline Amish More Likely & $81.8 \%$ & $54.8 \%$ & $66.0 \%$ \\
Amish Less Likely & $18.2 \%$ & $45.2 \%$ & $34.0 \%$ \\
\hline
\end{tabular}

Chi-Square $=4.176,1$ degree of freedom, significance $=.041$

Table 5

Amish Likelihood to Remain in Dairying and Type of Milk Sold

\begin{tabular}{lccc}
\hline "“"Compared with other Wisconsin farmers & \multicolumn{2}{c}{ "Do dairy farms in your church district transport their } \\
milk in cans?"
\end{tabular}

Chi-Square $=4.141,1$ degree of freedom, significance $=.042$

\section{Table 6}

Amish Likelihood to Remain in Dairying and Church District Having at Least One Dairy Herd

\begin{tabular}{|c|c|c|c|}
\hline \multirow{2}{*}{$\begin{array}{l}\text { "Compared with other Wisconsin farmers } \\
\text { who milk fewer than a hundred cows, do } \\
\text { you think Amish dairy farmers are more or } \\
\text { less likely to remain in the dairy business?" }\end{array}$} & \multicolumn{3}{|c|}{$\begin{array}{c}\text { "How many of the farms in your district have dairy } \\
\text { herds?" }\end{array}$} \\
\hline & One or More & None & $\begin{array}{l}\text { Total } \\
(\mathrm{N}=54)\end{array}$ \\
\hline Amish More Likely & $70.0 \%$ & $0.0 \%$ & $68.7 \%$ \\
\hline Amish Less Likely & $30.0 \%$ & $100.0 \%$ & $30.6 \%$ \\
\hline
\end{tabular}

Chi-Square $=7.958,1$ degree of freedom, significance $=.005$

Clearly, all of the respondents from districts lacking dairying felt that Amish farmers are less likely to remain in the dairy business than other small Wisconsin dairy operators. In contrast, when the author surveyed Amish ministers and bishops four years earlier, a respondent from a settlement that lacked dairying indicated interest by members of his community in establishing dairy herds. Thus, responses to a variety of questions point toward waning involvement in dairying. 


\section{Increasing Engagement in other Occupations}

The survey also sought information regarding engagement in two other occupations. Totals from the 69 respondents indicate that $49.6 \%$ of the Amish farms had dairy herds and that $29.6 \%$ of Amish farms focused on growing produce. Greenhouses are found on 19.2\% of Wisconsin's Amish farms. When asked, "By 2025, do you expect that a larger or smaller percentage of the farmers in your church district will grow produce?" three-fifths expected a larger percentage, with only one respondent expecting a decrease (Table 7).

\section{Table 7}

Expected Change in Produce Growing in Church District by 2025

\begin{tabular}{lcr}
\hline Question & Change & $\mathrm{N}=57$ \\
\hline "By 2025, do you expect that a larger or smaller & Larger Percent & $59.6 \%$ \\
percentage of the farmers in your church district will & Same Percent & $38.6 \%$ \\
grow produce?" & Smaller Percent & $1.8 \%$ \\
\hline
\end{tabular}

The number of Amish households that operate a sawmill or woodworking shop $(15.0 \%$ of total households) slightly exceeds the number of farms that focus on growing produce $(14.5 \%$ of households). When asked, "By 2025, do you expect that a larger or smaller percentage of the Amish men in your church district will work at a sawmill or woodworking shop?" nearly twofifths of the respondents indicated a larger percentage (Table 8). The remainder expected the same percentage, with none expecting a decrease.

\section{Table 8}

Expected Change in Woodworking in Church District by 2025

\begin{tabular}{lcc}
\hline Question & Change & $\mathrm{N}=58$ \\
\hline "By 2025, do you expect that a larger or smaller & Larger Percent & $39.7 \%$ \\
percentage of the farmers in your church district will & Same Percent & $60.3 \%$ \\
work at a sawmill or woodworking shop?" & Smaller Percent & $0.0 \%$ \\
\hline
\end{tabular}

Even though half of Amish households live on an active farm and many others have a barn or shelter for their horses, $63.3 \%$ of the survey respondents indicated that occupations related to woodworking, carpentry, and sawmills are the single leading source of employment in their settlement. Only 5\% explicitly mentioned dairying, $8 \%$ indicated produce, and 17\% reported farming. Altogether these three agricultural activities comprised the leading source of employment in $30 \%$ of the Amish settlements. The Amish in Wisconsin have now joined those in other states where farming no longer dominates their employment. 


\section{Continuing Occupational Change}

Occupational change among Wisconsin's Amish is definitely underway. We will increasingly see evidence of other economic activities, just as numerous scholars have described elsewhere, such as in Lancaster County, Pennsylvania (Smith et al., 1997), Holmes County, Ohio (Kreps et al., 1994; Lowery \& Noble, 2000; Hurst \& McConnell, 2010), and Elkhart-LaGrange Counties, Indiana (Nolt \& Meyers, 2007) over the past several decades. The changes in Wisconsin just did not come as early. We visually see the evidence, such as large greenhouses in many settlements and the produce auction houses in the Fennimore, Kingston-Dalton, Cashton, and Loyal communities. While the numerous sawmills in the Cashton settlement drew scholarly notice a decade and a half ago (Heasley, 2005), Amish sawmills are increasingly seen in the Augusta, Greenwood, and New Auburn communities. While many households in Cashton and Greenwood are engaged in both sawmill or other woodworking activities and dairying, increasingly those in Augusta are leaving dairying, while New Auburn has no dairying.

This study largely focused on the decline in Amish dairying between March 1, 2018, and November 1, 2019, after which losses of Amish dairy herds slowed for several months. Until conditions caused the precipitous decline among Wisconsin's dairy farmers overall, Amish dairy operations had grown in number, although the proportion of Amish households with dairy herds was slowly decreasing. Yet, given conditions that prevailed beginning in 2018, all dairy farmers were stressed, and Amish dairymen joined the exodus, with alternate occupations gaining in attraction.

As this paper went for review, Wisconsin's dairy farmers, both Amish and English, as the Amish call all those who are not of their group, faced cataclysmic challenges associated with the COVID-19 pandemic. Milk prices plummeted and demand for milk by processors dropped so much that numerous press reports described dairymen pouring milk onto their fields. Unemployment quickly rose to Great Depression levels. With so many financially stressed consumers, undoubtedly the market for goods coming from other Amish occupations has been, or will shortly be, also affected. The state governor's stay-at-home order went into effect in midMarch, and April 1, 2020, statistics regarding the number of Wisconsin's milk cow herds, which showed a monthly loss of 30 herds of which only two produced can milk, were too early to show the effects. The decline remained relatively small over the next several months, with Wisconsin losing an additional 119 milk cow herds between April 1, 2020, and July 1, 2020 (NASS-W, 2020), including four that used milk cans.

While Amish dairymen will certainly experience consequences, which will undoubtedly spur future scholarly inquiry, one wonders how their engagement in multiple enterprises, their reliance upon family and community help, and their partly subsistence lifestyle will shelter them. As one Hillsboro respondent explained, "It is our way of making a living." During the economic slump of 2008, the rate of dairy herd losses overall in Wisconsin remained relatively stable. Will that occur again during this far sharper economic crisis? Indeed, as one minister or bishop in Hillsboro noted, "We do not know what the future holds, but we do know who holds the future. I'd assume if dairy continues as it has, there will be very little deviation from as it is now." 


\section{References}

Anderson, C., \& Kendra, L. (2015). What kinds of places attract and sustain Amish populations? Rural Sociology, 80(4), 483-511. https://doi.org/10.1111/ruso.12083

Barrett, R. (2018, December 21). Amish dairy farmers at risk of losing their living and way of life as their buyer drops their milk. Milwaukee Journal Sentinel. https://www.jsonline.com/story/money/2018/12/21/amish-dairy-farmers-risk-losing-theirliving/2378827002/

Bennett, R. (2019, January 3). Amid ongoing dairy farm crisis, Amish and other farmers dropped at the beginning of the year find new milk buyers. Milwaukee Journal Sentinel.

https://www.jsonline.com/story/money/2019/01/03/amish-other-sw-wisconsin-dairy-farmersfind-milk-buyers-last-minute/2467878002/

Bentley, S., \& Saupe, W. E. (1990). Exits from farming in southwestern Wisconsin, 1982-1986. (Agricultural Economics Report No. 631). U.S. Department of Agriculture, Economic Research Service.

Cross, J. A. (1989). Wisconsin's changing dairy industry and the dairy termination program. Transactions of the Wisconsin Academy of Sciences, Arts \& Letters, 77, 11-26.

Cross, J. A. (2001). Change in America's dairyland. The Geographical Review, 91(4), 702-714. https://doi.org/10.1111/j.1931-0846.2001.tb00249.x

Cross, J. A. (2003). Amish surnames, settlement patterns, and migration. Names, 51(3-4), 193-214. https://doi.org/10.1179/nam.2003.51.3-4.193

Cross, J. A. (2004). Expansion of Amish dairy farming in Wisconsin. Journal of Cultural Geography, 21(2), 77-101. https://doi.org/10.1080/08873639009478260

Cross, J. A. (2006). Restructuring America's dairy farms. The Geographical Review, 96(1), 1-23. https://doi.org/10.1111/j.1931-0846.2006.tb00385.x

Cross, J. A. (2014). Continuity and change: Amish dairy farming in Wisconsin over the past decade. The Geographical Review, 104(1), 52-70. https://doi.org/10.1111/j.19310846.2014.12004.x

Cross, J. A. (2018). Occupation patterns of Amish settlements in Wisconsin. Journal of Amish and Plain Anabaptist Studies, 6(2), 192-212. https://doi.org/10.18061/1811/87095

Cross, J. A. (2021, in press). Changes in America's dairyland since the 2012 and 2017 Agricultural Censuses. In D. Drake (Ed.), Economic geographies of US livestock: Taking stock and mapping it. Palgrave Macmillan.

Day-Farnsworth, L., McCown, B., Miller, M., \& Pfeiffer, A. (2009). Scaling up: Meeting the demand for local food. Board of Regents of the University of Wisconsin System, Center for Integrated Agricultural Systems. https://cias.wisc.edu/wpcontent/uploads/sites/194/2010/01/baldwin_web final1.pdf

Donnermeyer, J. (2019). Settlement location by state/province, as of April 30, 2019. [Unpublished table]. 
Eisen, M. (2020, April 4). Organic Valley struggles, then surges in turbulent dairy market. Wisconsin Examiner. https://wisconsinexaminer.com/2020/04/20/organic-valley-strugglesthen-surges-in-turbulent-dairy-market/

Grahn, G. K., \& Wingate, R. G. (1988). The Wisconsin Hill and Valley Cheese Factory: A joint venture between Amish and non-Amish. The Wisconsin Geographer, 4, 65-71.

Heasley, L. (2005). A thousand pieces of paradise: Landscape and property in the Kickapoo Valley. University of Wisconsin Press.

Hurst, C. E., \& McConnell, D. L. (2010). An Amish paradox: Diversity and change in the world's largest Amish community. Johns Hopkins University Press.

Johnson, R. (2014, June 30). Old Country Farmers' Co-op continues can tradition: Amish in three Wisconsin counties contribute milk for cheesemaking. Dairy Star. https://dairystar.com/Content/News/Print-edition-click-here-/Article/Old-Country-FarmersCo-op-continues-can-tradition/1/1/10022

Kent, R. B., \& Neugebauer, R. J. (1990). Identification of ethnic settlement regions: AmishMennonites in Ohio. Rural Sociology, 55(3), 425-441. https://doi.org/10.1111/j.15490831.1990.tb00692.x

Kraybill, D. B., Johnson-Weiner, K. M., \& Nolt, S. M. 2013. The Amish. Johns Hopkins University Press.

Kreps, G. M., Donnermeyer, J. F., \& Kreps, M. W. (1994). The changing occupational structure of Amish males." Rural Sociology, 59(4), 708-719. https://doi.org/10.1111/j.15490831.1994.tb00556.x

Lowery, S., \& Noble, A. G. (2000). The changing occupational structure of the Amish of the Holmes County, Ohio, settlement. The Great Lakes Geographer, 7(1), 26-37.

Miller, E. E. (2014). Wisconsin Amish Directory 2014.

Miller, P. (2009). Wisconsin Amish Directory 2009.

National Agricultural Statistics Service, Wisconsin Field Office. (2010). 2010 dairy producer survey. National Agricultural Statistics Service.

https://www.nass.usda.gov/Statistics_by_State/Wisconsin/Publications/Dairy/Other_Surveys/ Dairy_OP_Release 10.pdf

National Agricultural Statistics Service, Wisconsin Field Office. (2018-2020). Wisconsin milk cow herds by type of milk produced. First and last reports: https://www.nass.usda.gov/Statistics by_State/Wisconsin/Publications/Dairy/2018/WI Dair y\%20Herd 01-18.pdf and https://www.nass.usda.gov/Statistics by State/Wisconsin/Publications/Dairy/2020/WIDairyHerd-07-20.pdf (Reports issued first day of each month.)

National Agricultural Statistics Service, Wisconsin Field Office. (2020). Number of monthly milk cow herds, Wisconsin, 2004 to current. https://www.nass.usda.gov/Statistics by_State/Wisconsin/Publications/Dairy/Historical_Dat a_Series/brt2004.pdf 
Nolt, S. M., \& Meyers, T. J. (2007). Plain diversity: Amish cultures and identities. Johns Hopkins University Press.

Raber, A. B. (2019). The new American almanac (50th ed.). Aden B. Raber.

Shepel, J. (2019, January 9). Salemville Cheese Co-op creates market for Amish farmers' milk. Wisconsin State Farmer. https://www.wisfarmer.com/story/news/2019/01/09/new-cheeseplant-positions-co-op-growth-and-success-amish/2515832002/

Smith, E. L. (1968). Amish names. Names, 16(2), 105-110. https://doi.org/10.1179/nam.1968.16.2.105

Smith, S. M., Findeis, J. L., Kraybill, D. B., \& Nolt, S. M. (1997). Nonagricultural microenterprise development among the Pennsylvania Amish: a new phenomenon. Journal of Rural Studies, 13(3), 237-251. https://doi.org/10.1016/S0743-0167(97)00018-1

U.S. Department of Agriculture, Agricultural Marketing Service. (2020). Organic integrity database. https://organic.ams.usda.gov/integrity/

Wisconsin Agricultural Statistics Service. (2012). 2012 Wisconsin Agricultural Statistics. Wisconsin Department of Agriculture, Trade, and Consumer Protection and National Agricultural Statistics Service, Wisconsin Field Office.

Wisconsin Agricultural Statistics Service. (2018). 2018 Wisconsin Agricultural Statistics. Wisconsin Department of Agriculture, Trade, and Consumer Protection and National Agricultural Statistics Service, Wisconsin Field Office.

Wisconsin Agricultural Statistics Service. (2019). 2019 Wisconsin Agricultural Statistics. Wisconsin Department of Agriculture, Trade, and Consumer Protection and National Agricultural Statistics Service, Wisconsin Field Office.

Wisconsin Agricultural Statistics Service. (2020). 2020 Wisconsin Agricultural Statistics.

Wisconsin Department of Agriculture, Trade, and Consumer Protection and National Agricultural Statistics Service, Wisconsin Field Office.

Wisconsin Department of Agriculture, Trade, and Consumer Protection. (2002). April 2002 Dairy Producers. [Data set].

Wisconsin Department of Agriculture, Trade, and Consumer Protection. (2012). April 2012 Dairy Producers. [Data set].

Wisconsin Department of Agriculture, Trade, and Consumer Protection. (2018). April 2018 Dairy Producers. [Data set].

Wisconsin Department of Agriculture, Trade, and Consumer Protection. (2019a). March 2019 Dairy Producers. [Data set].

Wisconsin Department of Agriculture, Trade, and Consumer Protection. (2019b). June 2019 Dairy Producers. [Data set].

Wisconsin Department of Agriculture, Trade, and Consumer Protection. (2019c). November 2019 Dairy Producers. [Data set].

Wisconsin Department of Agriculture, Trade, and Consumer Protection. (2020a). March 2020 Dairy Producers. [Data set]. 
Wisconsin Department of Agriculture, Trade, and Consumer Protection. (2020b). July 2020 Dairy Producers. [Data set]. Yoder, F. (2018). Wisconsin Amish directory 2018. Schlabach Printers.

Young Center for Anabaptist and Pietist Studies. (2018). Amish population, 2018. Amish Studies.

https://groups.etown.edu/amishstudies/files/2019/07/Amish Population by State 2018.pdf 